\title{
Isolation of Nonhistone Proteins from Pig Thymus for Large Scale Preparation*
}

\author{
Yoshihiro Ohtaki**, Hiro-o Watanabe***, \\ Michiteru Yoshida*** and Kensuke Shimura***
}

\begin{abstract}
SUMMARY
A method is described for the large scale isolation of nonhistone proteins from salt-urea dissociated pig thymus chromatin. After precipitating DNA in a dissociated chromatin solution with $\mathrm{LaCl}_{3}$ at $\mathrm{pH} 7.9$, the chromosomal proteins in the supernatant were precipitated by raising the $\mathrm{pH}$ of the supernatant to 8.6. The chromosomal proteins in the precipitate were dissolved and separated into nonhistone proteins and histones by chromatography on SP-Sephadex C-25 using a sodium chloride stepwise elution. Almost all of the total nonhistone proteins in chromatin was eluted from the column at $0.25 \mathrm{M}$ and $0.3 \mathrm{M} \mathrm{NaCl}$.
\end{abstract}

Key words : isolation, nonhistone proteins, pig thymus.

Introduction

The nonhistone proteins (NHP) have been studied extensively ${ }^{1 \sim 4)}$, partly because of their intrinsic interest $^{5,6)}$, and partly because of the virtually universal expectation that some of them must function as specific regulators of gene transcription in eukaryotic $\operatorname{organisms}^{7 \sim 10)}$. To develop more detailed studies on the action of NHP in the expression of specific genes, it is quite desirable to establish a practical method to fractionate NHP and obtain the NHP fractions in enough quantity to be able to carry out protein-chemical or physico-chemical works in addition to biochemical ones. Van den
Broek et al. have reported ${ }^{11)}$ a method for the isolation of NHP. They dissociated the chromatin in 3M $\mathrm{NaCl}-10 \mathrm{mM}$ Tris- $\mathrm{HCl}(\mathrm{pH} 8.0)$ and removed DNA by gel filtration on Bio-Gel A-50m. Bhorjee \& Pederson have also reported ${ }^{12)}$ a method for the isolation of chromatin proteins. They dissociated the chromatin in guanidine $\mathrm{HCl}$-urea and removed DNA by ultracentrifugation. The removal of DNA from the dissociated chromatin solution by centrifugation or gel filtration is not always suitable for the large scale isolation of NHP, owing to the requirements of long-time centrifugation or a large volume of gel materials. On the other hand, Goodwin et al. have reported a method for the

* 豚胸腺非ヒストン蛋白質の大量調製法.

** 大滝義博, 東北大学農学部生物化学教室(現所属及び連絡先, 野村生物科学研究所, 研究部, 臨床生化学 - 血液 学 $\mathrm{G}$ )

*** 渡辺博夫, 吉田充輝, 志村憲助, 東北大学農学部生物化学教室.

(Accepted August 15, 1984, Receivéd October 31, 1984) 
isolation of loosely bound NHP. They extracted the loosely bound NHP from the chromatin with $0.35 \mathrm{M}$ $\mathrm{NaCl}^{13 \sim 15)}$.

In our laboratory, we have taken a new approach to the preparation of chromosomal proteins, using lanthanum chloride as a selective precipitant of free DNA from dissociated chromatin in $5 \mathrm{M}$ urea-2M $\mathrm{NaCl}$-Tris- $\mathrm{HCl}$ buffer ( $\mathrm{pH}$ 7.9), leaving the chromosomal proteins in the supernatant solution ${ }^{16,17)}$. This method, however, has a disadvantage in that the concentration of the chromosomal protein obtained is too low to submit to further fractionation procedures in large scale experiment.

In this report, an attempt is made to overcome this disadvantage by precipitating, at a higher $\mathrm{pH}$, the chromosomal proteins as their lanthanum salts with a yield of around $70 \%$ of total chromosomal proteins. Thus, the $\mathrm{LaCl}_{3}$ method can be used for large-scale preparation of NHP under relatively mild conditions.

\section{Materials and Methods}

\section{Materials}

Sephadex G-15 and SP-Sephadex C-25 (40-120 $\mu$, $2.3 \pm 0.3 \mathrm{meq} / \mathrm{g}$ ) were purchased from Pharmacia Fine Chemicals, 2-mercaptoethanol from Nakarai Chemicals, $\mathrm{LaCl}_{3} \cdot 7 \mathrm{H}_{2} \mathrm{O}$ from Mitsuwa's Pure Chemicals. Specially prepared reagents, acrylamide (monomer), N, N, N', N'-tetramethylethylenediamine and N,N'-methylenebisacrylamide were obtained from Wako Pure Chemical Industries. Coomassie brilliant blue $\mathrm{R}$ was obtained from Sigma Chemical Company. Urea was purchased from Wako Pure Chemical Industries, and deionized with Amberlite MB-3 just before use. All other reagents were of the purest grade commercially available.

\section{Preparation of Chromatin from Pig Thymus}

The preparation of chromatin from fresh pig thymus was carried out by the method described previously $^{16)}$ with a slight modification. All steps throughout the fractionation of nońhistone proteins were carried out at $0-4^{\circ} \mathrm{C}$. Minced pig thymus was homogenized in 6 volumes of $0.14 \mathrm{M} \mathrm{NaCl}, 0.01 \mathrm{M}$ sodium citrate and $1 \mathrm{mM}$ phenylmethylsulfonylfluoride (PMSF) (pH7.0) with a Waring blendor and filtered through two layers of gauze. The filtrate was centrifuged at $2,500 \times \mathrm{g}$ for $15 \mathrm{~min}$. The sediment was then washed five times with the $\mathrm{NaCl}$ sodium citrate solution in the same way. The precipitate was next resuspended in $0.05 \mathrm{M}$ Tris $-\mathrm{HCl}(\mathrm{pH}$ 7.6) $(3 \mathrm{ml} / \mathrm{g}$ fresh weight of pig thymus), and centrifuged at $6,000 \times \mathrm{g}$ for $20 \mathrm{~min}$. The washing procedure was repeated once again in the same manner. Then, the precipitate was homogenized with two liters of $1 \mathrm{mM}$ PMSF solution using a Waring blendor. The chromatin suspension obtained was poured into an equal volume of $4 \mathrm{M}$ $\mathrm{NaCl}$ by rapid stirring. The viscous solution of chromatin was sheared by a Potter-Elvehjem homogenizer and centrifuged at $35,000 \times \mathrm{g}$ for $60 \mathrm{~min}$ to remove unsheared chromatin. The supernatant was used for the isolation of whole chromosomal proteins.

\section{Dissociation of Chromatin}

In order to dissociate the chromatin into DNA and chromosomal proteins, solid $\mathrm{NaCl}, 8 \mathrm{M}$ deionized urea, $0.5 \mathrm{M}$ Tris- $\mathrm{HCl}(\mathrm{pH}$ 7.9) and 2-mercaptoethanol were added to the chromatin solution obtained above to give final concentrations of $5 \mathrm{M}$ urea, $2 \mathrm{M} \mathrm{NaCl}, 0.05 \mathrm{M}$ Tris- $\mathrm{HCl}$ and $2 \mathrm{mM}$ 2-mercaptoethanol ( $\mathrm{pH}$ 7.9). The DNA concentration of dissociated chromatin solution was adjusted to $400 \mu \mathrm{g}$ per ml. The solution was allowed to stand at $4^{\circ} \mathrm{C}$ for $24 \mathrm{~h}$. with occasional shaking.

Precipitation of DNA by $\mathrm{LaCl}_{3}$ and Concentration of Whole Chromosomal Proteins

Selective precipitation of DNA from the dissociated chromatin solution and concentration of whole chromosomal proteins in the supernatant were carried out as described in "Results".

Fractionation of the Chromosomal Proteins on SP-Sephadex C-25

About $500 \mathrm{mg}$ of the chromosomal protein fractions (pH8.6 Ppt. or pH8.6 Sup., see Table 1) dial- 
yzed against $0.02 \mathrm{M}$ Na-acetate buffer (pH5.2) containing $5 \mathrm{M}$ urea, $0.25 \mathrm{M} \mathrm{NaCl}, 3 \mathrm{mM}$ 2-mercaptoethanol and $1.5 \mathrm{mM}$ EDTA were applied to a SP-Sephadex C-25 column $(4.7 \times 35 \mathrm{~cm})$ preequilibrated with the same $\mathrm{Na}$-acetate buffer and eluted stepwise with $0.25,0.3,0.4$ and $1.0 \mathrm{M} \mathrm{NaCl}$, successively, in 0.02M Na-acetate buffer (pH5.2) containing $5 \mathrm{M}$ urea, $3 \mathrm{mM} 2-$ mercaptoethanol and $1.5 \mathrm{mM}$ EDTA. The flow rate was about $30 \mathrm{ml}$ per $\mathrm{h}$. The fractions collected from the column were combined into seven pools. After the determination of protein contents, each protein pool was dialyzed extensively against water, and lyophilized.

\section{Gel Electrophoresis of Protein}

Sodium dodecyl sulfate (SDS) gel electrophoresis was performed as described previously ${ }^{18}$. The proteins were incubated at $37^{\circ} \mathrm{C}$ overnight in $0.01 \mathrm{M}$ Na-phosphate buffer (pH7.0)-1\% SDS-1\% 2 -mercaptoethanol-8M urea. The running gels $(5 \times$ $85 \mathrm{~mm}$ ) were made up from $0.1 \mathrm{M}$ sodium phosphate buffer (pH7.0), $10 \%$ acrylamide, $0.27 \% \mathrm{~N}, \mathrm{~N}^{\prime}-$ methylenebisacrylamide, $0.15 \% \quad \mathrm{~N}, \mathrm{~N}, \mathrm{~N}^{\prime}, \mathrm{N}^{\prime}$-tetramethylethylenediamine, $0.075 \%$ ammonium persulfate and $4 \mathrm{M}$ urea. The samples were run at a constant current of $7 \mathrm{~mA}$ per tube for about $5 \mathrm{~h}$, and were then stained with $0.25 \%$ Coomassie brilliant blue in $7 \%$ acetic acid $-45 \%$ methanol for $2 \mathrm{~h}$, and destained by diffusion in $7 \%$ acetic acid- $5 \%$ methanol.

\section{General Methods}

Pig thymus whole histone was separated by the procedure described previously ${ }^{19)}$. DNA was determined by the diphenylamine method ${ }^{20)}$, with pig thymus DNA as a standard. In some experiments, the concentration of DNA in chromatin was determined by measuring the absorbance, assuming that a 22.0 optical-density unit at $260 \mathrm{~nm}$ was equivalent to $1 \mathrm{mg}$ of DNA per ml. Protein was determined according to the method of Lowry et $\mathrm{al}^{21}$. with bovine serum albumin as a standard.

\section{Results}

\section{Effect of $\mathrm{LaCl}_{3}$ Concentration on the Precipita- tion of DNA}

It was ascertained that in the solution of $5 \mathrm{M}$ urea, $2 \mathrm{M} \mathrm{NaCl}, 0.05 \mathrm{M}$ Tris- $\mathrm{HCl}$ and 2mM 2-mercaptoethanol (pH7.9), about 93\% of chromosomal proteins were dissociated from DNA by gel filtration on Sephadex G-200 (data not shown). To precipitate the DAN selectively from the dissociated chromatin solution, the $\mathrm{LaCl}_{3}$ method previously described in

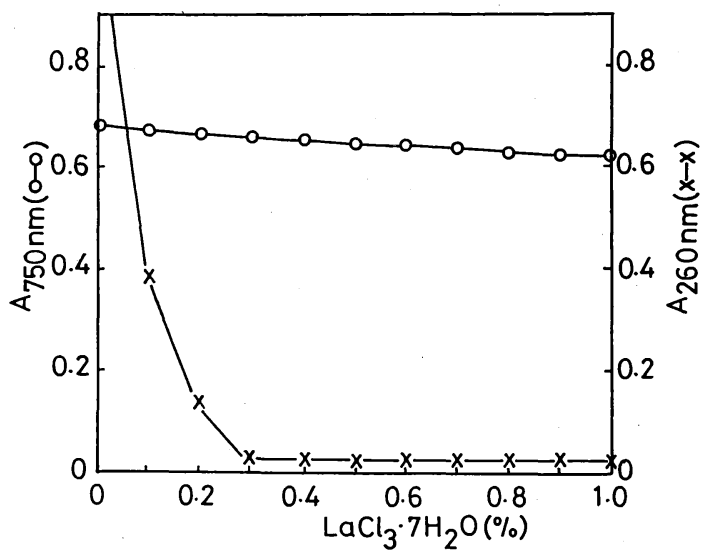

Fig.1. Effect of concentration of $\mathrm{LaCl}_{3}$ on the precipitation of DNA. For the preparation of dissociated chromatin, solid $\mathrm{NaCl}, 8 \mathrm{M}$ deionized urea, $0.5 \mathrm{M}$ Tris$\mathrm{HCl}(\mathrm{pH} 7.9)$ and 2-mercaptoethanol were added to the chromatin solution to give final concentrations of $5 \mathrm{M}$ urea, $2 \mathrm{M} \mathrm{NaCl}, 0.05 \mathrm{M}$ Tris- $\mathrm{HCl}$ and $2 \mathrm{mM} 2-$ mercaptoethanol (pH7.9). The DNA concentration of the dissociated chromatin solution was adjusted to $400 \mu \mathrm{g}$ per ml. Nine $\mathrm{ml}$ of dissociated chromatin solutions were taken into test tubes and one $\mathrm{ml}$ of $\mathrm{LaCl}_{3} \cdot 7 \mathrm{H}_{2} \mathrm{O}$ solution, previously dissolved in the Tris$\mathrm{HCl}$ buffer described above, was added to each dissociated chromatin solution to make the concentration of $\mathrm{LaCl}_{3} \cdot 7 \mathrm{H}_{2}$ $\mathrm{O}$ as indicated in the figure. After standing for $1 \mathrm{~h}$ at $0 \sim 4^{\circ} \mathrm{C}$, the solution was centrifuged at $40,000 \times \mathrm{g}$ for $1 \mathrm{~h}$. An aliquot of the supernatant was used for the determination of DNA and protein. 
the case of calf thymus chromatin was used ${ }^{16)}$ with a slight modification. As shown in Fig. 1, at concentrations higher than $0.3 \%$ of $\mathrm{LaCl}_{3} \cdot 7 \mathrm{H}_{2} \mathrm{O}$, about $98 \%$ of total DNA was precipitated as lanthanum salt. In this condition, however, chromosomal proteins were hardly precipitated. Thus, we adopted a concentration of $0.7 \% \mathrm{LaCl}_{3} \cdot 7 \mathrm{H}_{2} \mathrm{O}$ in the present experiment.

Effect of $\mathrm{pH}$ on the Precipitation of DNA by $\mathrm{LaCl}_{3}$

The precipitation of DNA by $\mathrm{LaCl}_{3}$ was sensitively dependent on the $\mathrm{pH}$ of the dissociated chromatin solution. In a pH range from 7.8 to 8.0 , a gelatinous precipitate of DNA appeared. In a $\mathrm{pH}$ range higher than 8.0, however, chromosomal proteins as well as

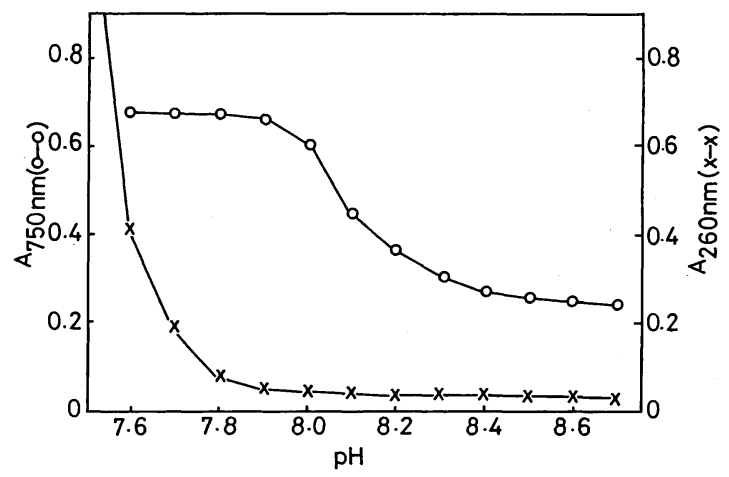

Fig.2. Effect of $\mathrm{pH}$ on the precipitation of DNA. For preparation of dissociated chromatin, solid $\mathrm{NaCl}, 8 \mathrm{M}$ deionized urea, 2-mercaptoethanol and 0.5M Tris$\mathrm{HCl}$ of various $\mathrm{pH}$ values, as indicated in the figure, were added to the chromatin solution to give final concentrations of $5 \mathrm{M}$ urea, $2 \mathrm{M} \mathrm{NaCl}, 0.05 \mathrm{M}$ Tris- $\mathrm{HCl}$ and $2 \mathrm{mM} \mathrm{2-mercaptoethanol.}$ The DNA concentration of the dissociated chromatin solution was adjusted to $400 \mu \mathrm{g}$ per ml. Nine $\mathrm{ml}$ of dissociated chromatin solutions were taken into test tubes and one $\mathrm{ml}$ of $\mathrm{LaCl}_{3} \cdot 7 \mathrm{H}_{2} \mathrm{O}$ solution previously dissolved in the Tris- $\mathrm{HCl}$ buffer described above was added to each dissociated chromatin to make a final concentration of $0.7 \%$. Afțer standing for $1 \mathrm{~h}$ at $0 \sim 4^{\circ} \mathrm{C}$, the solution was centrifuged at $40,000 \times \mathrm{g}$ for $1 \mathrm{~h}$. DNA and protein in the supernatant were determined as described in Fig.1.
DNA were precipitated by $\mathrm{LaCl}_{3}$ (Fig. 2 ). Usually, a buffer solution of intermediate $\mathrm{pH}$ (7.9) was employed. The gelatinous precipitate of DNA was removed by centrifugation at $40,000 \times \mathrm{g}$ for $\mathrm{lh}$. The supernatant contained about $91 \%$ of whole chromosomal protein and $2 \%$ of total DNA.

\section{Precipitation of Chromosomal Proteins at a higher $\mathrm{pH}$}

The results of Fig. 2 indicates that fair amount, if not most of chromosomal proteins in the supernatant are precipitated by increasing $\mathrm{pH}$ above 8.1. Thus, an optimal pH for recovering the chromosomal proteins from the supernatant was searched for. Ten $\mathrm{ml}$ protein solutions of the supernatant were taken into test tubes with pH's adjusted from 8.0 to 9.6 with $2 \mathrm{~N} \mathrm{NaOH}$ at intervals of 0.2 . After standing at $0^{\circ} \mathrm{C}$ for $2 \mathrm{~h}$, the resulting precipitates were recovered by centrifugation at $10,000 \times \mathrm{g}$ for 15min. As shown in Fig. 3, the precipitation of

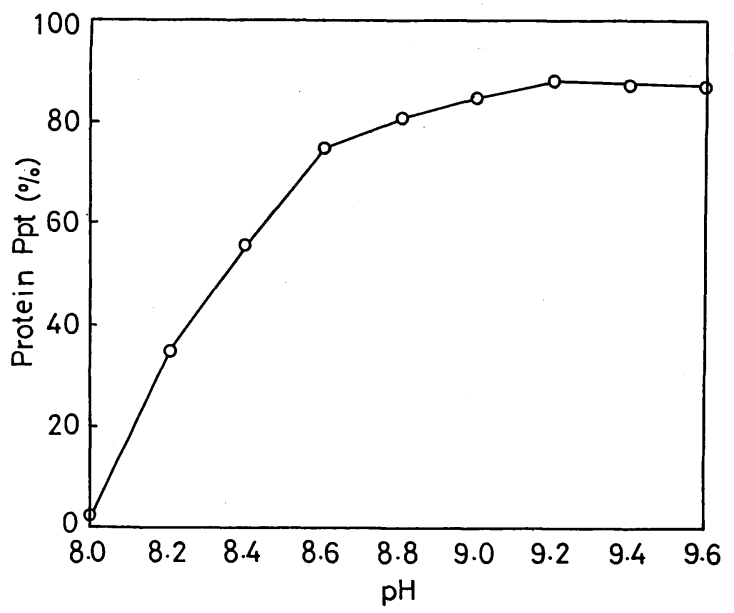

Fig.3. Effect of $\mathrm{pH}$ on the precipitation of chromosomal proteins. Ten $\mathrm{ml}$ of chromosomal protein solutions after precipitation of DNA were taken into test tubes and $\mathrm{pH}$ 's were adjusted from 8.0 to 9.6 with $2 \mathrm{~N} \quad \mathrm{NaOH}$ at intervals of 0.2 . After standing at $0^{\circ} \mathrm{C}$ for $2 \mathrm{~h}$, the resulting precipitates were recovered by centrifugation at 10,000 $\times \mathrm{g}$ for $15 \mathrm{~min}$. The protein content in the precipitate was determined after dissolving into $1 \mathrm{~N} \mathrm{NaOH}$. 
Table I. Fractionation of pig thymus chromosomal proteins by $\mathrm{LaCl}_{3}$ and $\mathrm{pH}$ treatments

\begin{tabular}{lcccc}
\hline Fraction & $\begin{array}{c}\text { Volumn } \\
(\mathrm{ml})\end{array}$ & $\begin{array}{c}\text { Protein Concn. } \\
(\mu \mathrm{g} / \mathrm{ml})\end{array}$ & $\begin{array}{c}\text { Total Protein } \\
(\mathrm{g})\end{array}$ & $\begin{array}{c}\text { Recovery } \\
(\%)\end{array}$ \\
\hline $\begin{array}{l}\text { Dissociated } \\
\text { chromatin }\end{array}$ & 36000 & 611 & 22.0 & 100 \\
$\begin{array}{l}\mathrm{LaCl} \text { Sup. } \\
\text { Fraction }\end{array}$ & 39000 & 513 & 20.0 & 91 \\
$\mathrm{pH} 8.6$ ppt. & 600 & 25333 & & 69 \\
Fraction & & & 15.2 & \\
pH 8.6 Sup. & 38400 & 120 & 4.8 & 22 \\
Fraction & & & & \\
\hline
\end{tabular}

chromosomal proteins increased gradually, and the maximum recovery of the proteins was attained at $\mathrm{pH} 9.2$ with à yield of about $88 \%$. In the present experiment, however, the $\mathrm{pH}$ of the solution in the large scale experiment was settled at 8.6 to minimize the danger of peptide-bond hydrolysis. In this $\mathrm{pH}$ condition, $75 \%$ of the chromosomal proteins was precipitated.

The precipitate of chromosomal proteins at $\mathrm{pH} 8.6$ (pH8.6 Ppt. fraction), dissolved in $0.02 \mathrm{M} \mathrm{CH}_{3} \mathrm{COOH}$ containing $0.25 \mathrm{M} \mathrm{NaCl}, 3 \mathrm{mM} 2$-mercaptoethanol and 1.5mM EDTA was subjected to gel filtration on Sephadex G-15 to remove $\mathrm{LaCl}_{3}$. The flow-through protein fraction from Sephadex G-15 was subjected to further fractionation. On the other hand, the supernatant fraction from the precipitation at $\mathrm{pH} 8$. 6 (pH8.6 Sup. fraction) was concentrated to about 5 $\mathrm{mg}$ protein per $\mathrm{ml}$ on an Amicon Ultrafiltration Membrane UM-2. The concentrated solution was also applied to gel filtration on Sephadex G-15 as described above. The recovery of chromosomal proteins is summarized in Table I.

Table II. Recovery of the chromosomal proteins from a SP-Sephadex C-25 column

\begin{tabular}{cccccc}
\hline Fraction & \multicolumn{2}{c}{$\mathrm{pH} 8.6 \mathrm{Ppt}$} & \multicolumn{2}{c}{ Fraction } & \multicolumn{2}{c}{$\mathrm{pH} 8.6$ Sup. } \\
\hline & $\mathrm{mg}$ & $\%$ & $\mathrm{mg}$ & $\%$ \\
\hline Total Protein Applied & 500 & 100 & Total Protein Applied & 500 & 100 \\
\hline A & 37.9 & 8.3 & $\mathrm{a}$ & 17.4 & 3.9 \\
B & 32.4 & 7.1 & $\mathrm{~b}$ & 28.5 & 6.4 \\
C & 13.2 & 2.9 & $\mathrm{c}$ & 25.8 & 5.8 \\
D & 42.0 & 9.2 & $\mathrm{~d}$ & 43.6 & 9.8 \\
E & 94.0 & 20.6 & $\mathrm{e}$ & 81.4 & 18.3 \\
F & 158.9 & 34.8 & $\mathrm{f}$ & 88.1 & 19.8 \\
G & 27.8 & 6.1 & $\mathrm{~g}$ & 70.8 & 15.9 \\
\hline Total Recovery $(\%)$ & & 91.3 & Total Recovery $(\%)$ & & 89.1 \\
\hline
\end{tabular}


Fractionation of the Chromosomal Proteins on SP-Sephadex C-25

The Sephadex fractions obtained above were dialyzed against $0.02 \mathrm{M}$ sodium acetate buffer ( $\mathrm{pH} 5$. 2) containing $5 \mathrm{M}$ urea, $0.25 \mathrm{M} \mathrm{NaCl}, 3 \mathrm{mM} 2-$ mercaptoethanol and $1.5 \mathrm{mM}$ EDTA and applied to a
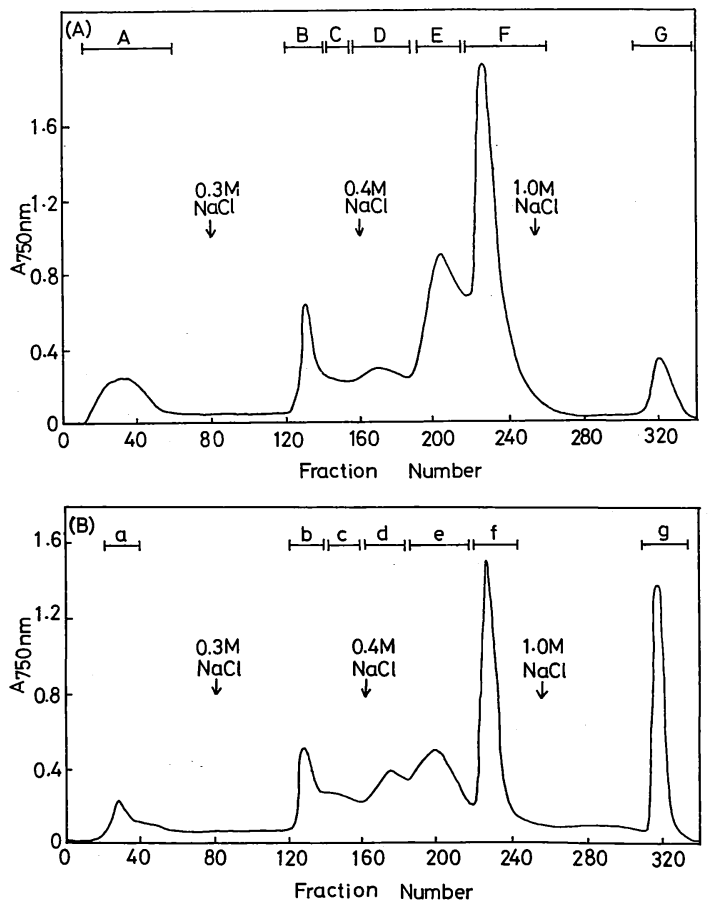

Fig.4. Elution profiles from a SP-Sephadex $\mathrm{C}-25$ column of $\mathrm{pH} 8.6$ Sup. (A) and pH8.6 Ppt. (B). About $500 \mathrm{mg}$ of the chromosomal protein fractions (pH8.6 Sup. or pH8.6 Ppt.) dialyzed against 0 . $02 \mathrm{M} \mathrm{Na}$-acetate buffer ( $\mathrm{HH} 5.2$ ) containing $5 \mathrm{M}$ urea, $0.25 \mathrm{M} \mathrm{NaCl}, 3 \mathrm{mM} 2$-mercaptoethanol and $1.5 \mathrm{mM}$ EDTA were applied to a SP-Sephadex C-25 column $(4.7 \times 35 \mathrm{~cm})$ preequilibrated with the same $\mathrm{Na}$-acetate buffer and eluted stepwise with $0.25,0.3,0.4$ and $1.0 \mathrm{M}$ $\mathrm{NaCl}$, successively, in $0.02 \mathrm{M} \mathrm{Na}$-acetate buffer (pH5.2) containing $5 \mathrm{M}$ urea, $3 \mathrm{mM}$ 2-mercaptoethanol and $1.5 \mathrm{mM}$ EDTA. The flow rate was about $30 \mathrm{ml}$ per $\mathrm{h}$. The arrows indicate the position where the different salt concentrations were applied to the column. The fractions combined into seven pools are indicated by bars above the column profiles.
SP-Sephadex C-25 column preequilibrated in the same buffer. Fig 4 A and 4 B show the chromatographic profiles of chromosomal proteins from a SP-Sephadex C-25 column by stepwise elution with buffers of increasing $\mathrm{NaCl}$ concentration. The eluates were combined into seven pools as indicated in the Figures, dialyzed against cold distilled water and lyophilized.

The sample applied to the column and each of the seven pools was analyzed for protein content to determine the recovery from the column. As shown in Table II, the average recoveries were $91 \%$ for pH8.6 Ppt. fraction and 89\% in pH8.6 Sup. fraction.

\section{Analysis of the SP-Sephadex C-25 Column Frac-} tions with SDS Gel Electrophoresis

The protein fractions obtained from the SPSephadex column were analyzed with SDS gel electrophoresis. Fig. 5A and 5B show the electrophoretic patterns of pH8.6 Ppt. and pH8.6 Sup. fractions, respectively. The results indicate that the two fractions were composed of virtually identical protein components. The passed-through fractions, $\mathrm{A}$ and $\mathrm{a}$, were shown to be composed of a large number of NHP with a high degree of heterogeneity and wide distribution of molecular weights. The molecular weight of the smallest NHP was found to be ca. 5,000. The largest NHP had molecular weight greater than 150,000 . The second fractions, $B$ and $b$, which were eluted from the column at $0.3 \mathrm{M} \mathrm{NaCl}$, revealed four bands of NHP. Further electrophoretic examinations of these fractions under various conditions such as acid-urea gel system described by Panyim and Chalkley ${ }^{22)}$ and twodimentional gel system described by Yeoman, L.C. et al. $^{23)}$ indicated that histones were absent in this fraction (data not shown). The molecular weights of each band were estimated to be 24,000 for $\mathbf{B}^{-1}$ and b-1 ; 21,000 for B-2 and b-2; 18,000 for B-3 and b-3 and 16,000 for $\mathrm{B}-4$ and $\mathrm{b}-4$. The third fractions, $\mathrm{C}$ and $\mathrm{c}$, which were also eluted from the column at 0 . $3 \mathrm{M} \mathrm{NaCl}$, contained histone $\mathrm{H} 2 \mathrm{~B}\left(\mathrm{C}^{-1}\right.$ and $\left.\mathrm{c}^{-1}\right)$, $\mathrm{H} 2 \mathrm{~A}(\mathrm{C}-2$ and $\mathbf{c}-2)$ and one of the major components of NHP (C-3 and $\mathbf{c}-3)$. The molecular weights of C 


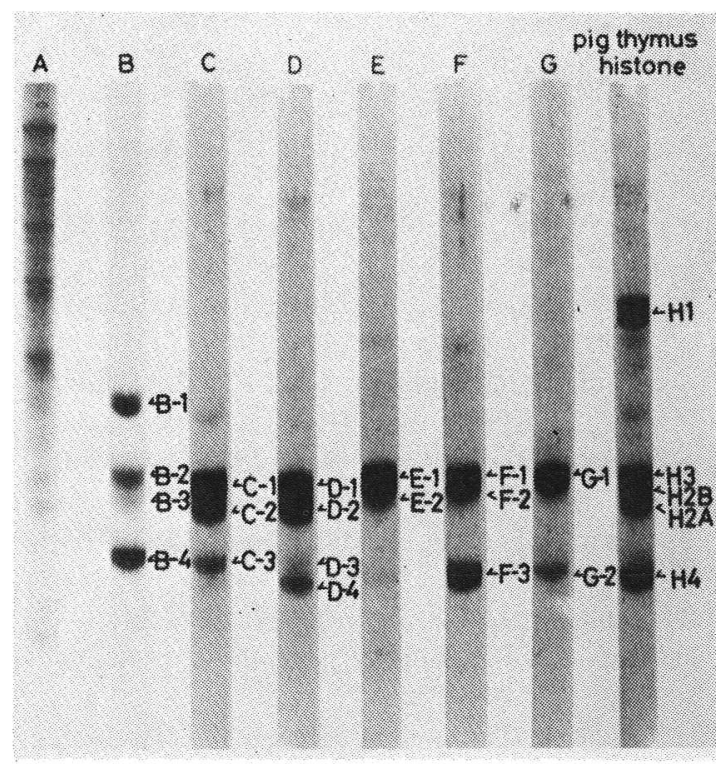

Fig.5A. SDS gel electrophoresis patterns of pH8.6 Sup. fraction. The electrophoresis was conducted as described in "Materials and Methods". The run was from the top to the bottom.

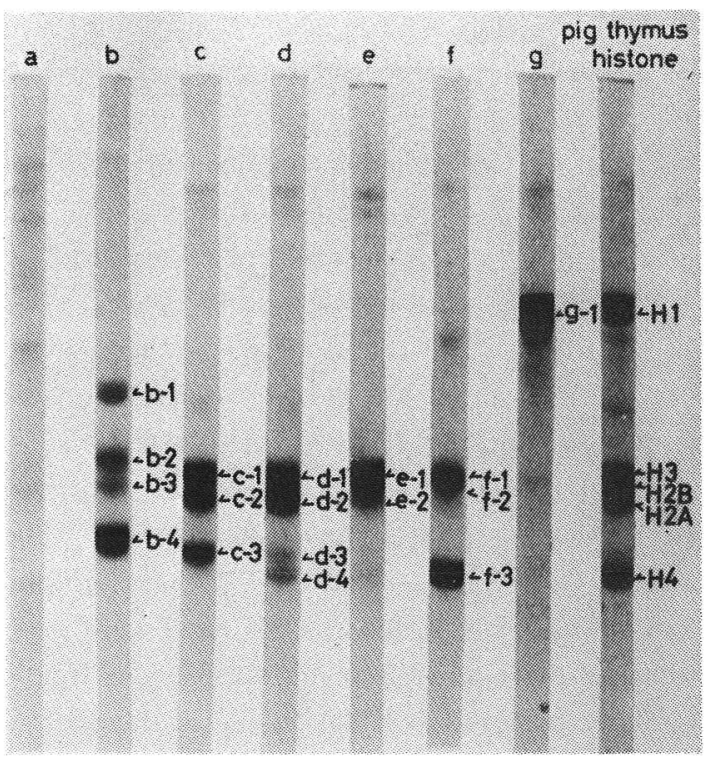

Fig.5B. SDS gel electrophoresis patterns of pH8.6 Ppt. fraction. The electrophoresis was conducted as described in "Materials and Methods". The run was from the top to the bottom.
-3 and $c-3$ were estimated to be about 15,000 . The forth fractions, which were eluted from the column at $0.4 \mathrm{M} \mathrm{NaCl}$ ( $\mathrm{D}$ and $\mathrm{d}$ ), contained histone $\mathrm{H} 2 \mathrm{~B}$ ( $\mathrm{D}^{-1}$ and $d-1$ ), H2A (D-2 and $d-2$ ) and H4 (D-4 and $d-4$ ) and few NHP (D-3 and $d-3$ ). The fifth fractions, which were also eluted from the column at $0.4 \mathrm{M}$ $\mathrm{NaCl}(\mathrm{E}$ and e), contained only histone $\mathrm{H} 3$ ( $\mathrm{E}-1$ and $\mathrm{e}^{-1}$ ) and $\mathrm{H} 2 \mathrm{~B}$ ( $\mathrm{E}^{-2}$ and $\mathrm{e}^{-2}$ ). The sixth fractions, which were eluted from the column at $0.4 \mathrm{M} \mathrm{NaCl}(F$ and $f$ ), contained histone $\mathrm{H} 2 \mathrm{~B}$ ( $F-2$ and $f-2), \mathrm{H} 3\left(F^{-1}\right.$ and $f-1)$ and $H 4\left(F^{-3}\right.$ and $\left.f-3\right)$.

The only apparent difference in the gel patterns between the $\mathrm{pH} 8.6 \mathrm{Ppt}$. and $\mathrm{pH} 8.6$ Sup. fractions was that the $1.0 \mathrm{M} \mathrm{NaCl}$ eluent from $\mathrm{pH} 8.6$ Ppt. fraction (Band G-1 and G-2) contained histone $\mathrm{H} 3$ and $\mathrm{H} 4$, while the $1.0 \mathrm{M} \mathrm{NaCl}$ eluent from $\mathrm{pH} 8.6$ Sup. contained only histone $\mathrm{H} 1$ (Band g-1).

These results indicate that almost all of the total NHP of chromatin was eluted from the column at 0 . $25 \mathrm{M}$ and $0.3 \mathrm{M} \mathrm{NaCl}$. The remaining NHP not eluted by $0.25 \mathrm{M}$ and $0.3 \mathrm{M} \mathrm{NaCl}$ were partially recovered in the $0.4 \mathrm{M} \mathrm{NaCl}$ eluent fraction.

\section{Discussion}

The procedure presented here provides a simple and rapid method for preparing NHP on a preparative scale, that is, even in gram amounts, with a recovery of about $70 \%$ of the original amount of NHP present in the chromatin. For good recovery of the protein, it is especially important to dissociate fully the chromosomal proteins from the DNA prior to the addition of $\mathrm{LaCl}_{3}$, and maintain the protein solution at $\mathrm{pH} 7.8$ to 8.0. At a higher $\mathrm{pH}$ than 8.0, the protein begins to be precipitated by $\mathrm{LaCl}_{3}$ together with DNA (Fig. 2 ).

The SDS gel electrophoresis patterns of $\mathrm{pH} 8.6$ Ppt. fraction are essentially the same as for that of $\mathrm{pH} 8.6$ Sup. fraction except for the $\mathbf{G}$ and $\mathrm{g}$ fractions. The $\mathbf{g}$ fraction shows distinct bands of histone $\mathrm{H} 1$, while the $\mathrm{G}$ fraction shows two bands of histone $\mathrm{H}$ 
3 and $\mathrm{H} 4$. Thus, we can say that the proteins in the pH8.6 Ppt. fraction represent actually almost all

species of NHP originally contained in the chromatin preparation. In addition, the recoveries of protein were also reasonable, as described in "Results". In this method, we could prepare several grams of each NHP fraction from pig thymus.

Goodwin et al. have reported ${ }^{13 \sim 15)}$ a method for the isolation and fractionation of NHP's. That is, proteins loosely bound to chromatin were extracted with a low concentration of salt $(0.35 \mathrm{M} \mathrm{NaCl})$. The proteins were further separated by precipitation with $2 \%$ and $10 \%$ trichloroacetic acid and by ion exchange chromatography on CM-Sephadex.By the use of these procedures, NHP's, loosely bound to chromatin, were well separated and characterized $^{24,25)}$, however, NHP's tightly bound to chromatin (NHP's not extractable with $0.35 \mathrm{M} \mathrm{NaCl}$, but extractable with $5 \mathrm{M}$ urea and $2 \mathrm{M} \mathrm{NaCl}$ ) or NHP's rigidly bound to chromatin (NHP's not extractable with $5 \mathrm{M}$ urea and $2 \mathrm{M} \mathrm{NaCl}$ ) were not obtained. Moreover, in these procedures nearly half of the $2 \%$ trichloroacetic acid precipitable fraction in loosely chromatin bound NHP, which contains a large number of acidic and neutral components, was virtually insoluble in usual buffer solutions ${ }^{26}$. On the other hand, in the presence of $5 \mathrm{M}$ urea and $2 \mathrm{M}$ $\mathrm{NaCl}$, NHP's tightly bound to chromatin were extracted together with loosely bound NHP's, and almost all the extracted chromosomal proteins were soluble in usual buffer solutions. Therefore, we decided to use the solution of $5 \mathrm{M}$ urea- $2 \mathrm{M} \mathrm{NaCl}^{-}$ $0.05 \mathrm{M}$ Tris- $\mathrm{HCl}$ and $2 \mathrm{mM} \mathrm{2-mercaptoethanol} \mathrm{(pH}$ 7.9) for the extraction of the chromosomal proteins.

Thus, this method can be used for the purpose of large scale isolation of loosely and tightly bound NHP's under a relatively mild conditions.

\section{References}

1) Reek G.R., et al. : Nature., $300: 76,1982$.

2 ) Isackson, P.J., et al. : J. Biol. Chem., 254 :
$5569,1979$.

3 ) Javaherian, K., et al. : Nucleic Acid Res., $6: 3569,1979$.

4) Mathis, D., et al. : Nucleic Acid Res., 8 , : 2577, 1980.

5 ) Boffa L.C., et al. : Cancer Res., $40: 1774$, 1980.

6) Ochs, R., et al. : Exp. Cell Res., 146: 139, 1983.

7 ) Paul, J. and Gilmour, R.S., : J. Mol. Biol., $34: 305,1968$.

$8)$ Kostraba, N.C. and Wang, T.Y. : J. Biol. Chem., $250: 8938,1975$.

9 ) Tsai, M.J., et al. : J. Biol. Chem., $251:$ 1960, 1976.

10) Stein, G., et al. : Nature, $257: 764,1975$.

11) Van den Broek, H.W.J., et al. : Biochemistry., $12: 229,1973$.

12) Bhorjee, J.S. and Pederson, T. : Biochim. Biophys. Acta., 418 : 154, 1976.

13) Goodwin, G.H. and Johns, E.W. : Eur. 'J. Biochem., 40 : 215, 1973.

14) Goodwin, G.H., et al. : Biochim. Biophys. Acta, 405 : 280, 1975.

15) Walker, J.M., et al. : Eur. J. Biochem., 76 : 461, 1977.

16) Yoshida, M. and Shimura, K. : Biochim. Biophys. Acta, $263:$ 690, 1972.

17) Yoshida, M., et al. : J. Biochem., $77: 1007$, 1975.

18) Yoshida, M. and Holobek, V. : Int. J. Biochem., $7: 259,1976$.

19) Yoshida, M., et al. : J. Biochem., 60 : 586, 1966.

20) Ashwell, G. : Methods in Enzymology, Vol. 3, pp. 73-105, Academic Press, New York, 1957.

21) Lowry, O.H., et al. : J. Biol. Chem., 193 : 265, 1951.

22) Panyim, S. and Chalkley, R. : Arch. Biochem. Biophys., $130: 337,1969$.

23) Yeoman, L.C., et al. : Biochem. Biophys. Res. Commun., 51 : 956, 1973.

24) Johns, E.W., et al. : The HMG Chromosomal Proteins, pp. 1, Academic Press, New York, 1982.

25) Sterner, R., et al. : J. Biol. Chem., 253 : 3830, 1978.

26) Yoshida, M., et al. : J. Biochem., $88: 425$, 1980. 
要

\section{旨}

遺伝情報発現に重要な役割をはたすと考えられてい る非ヒストン蛋白質 (NHP) の構造と機能を明らかに する目的の第 1 歩として豚胸腺から NHP を大量分離 する為の条件と回収された核蛋白質の SDS 電気泳動 による分析を行った.豚胸腺からクロマチンを単離後, $5 \mathrm{M}$ Urea, $2 \mathrm{M} \mathrm{NaCl}, 0.05 \mathrm{M}$ Tris- $\mathrm{HCl}, 2 \mathrm{mM} 2$ -mercaptoethanol 中で $93 \%$ の核蛋白質をDNA から 解離させた。これに塩化ランタンを加えてDNA を選 択的に沈殿させる条件を検討した結果, $0.7 \%$ 塩化ラン タン, $\mathrm{pH} 7.9$ の条件で $98 \%$ DNA が沈殿として，ま た，91\%の核蛋白質が上清に回収された。上清に残っ た核蛋白質は $\mathrm{pH}$ を8.6に上げるのみで75\%が沈殿と
して回収できた。 $\mathrm{pH}$ を8.6に上昇させた後の上清 （pH8.6 Sup.）と沈殿（pH8.6 Ppt）に含まれる蛋白 質分子種の異同を知る目的で，両者を SP-Sephadex C -25 による $\mathrm{NaCl}$ 濃度の段階的上昇により溶出させた のち各溶出画分を SDS 電気泳動で分析した所, 大部分 の NHP は SP-Sephadex C-25の0.25Mおよび0.3M $\mathrm{NaCl}$ 溶出画分に溶出すること, $\mathrm{pH} 8.6 \mathrm{Sup}$ と $\mathrm{pH} 8.6$ Ppt 画分で異なるのは七ストン画分のみであることが 明らかとなった。これにより，NHPの分離の目的には pH8.6 Ppt.画分を使用しうること, さらに, これまで, その性質が明らかとなっていない DNA に強固に結合 した NHP を分離する方法としても本法が使用できる ことがわかった。 